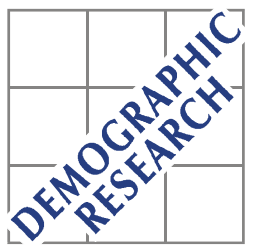

Demographic Research a free, expedited, online journal of peer-reviewed research and commentary in the population sciences published by the Max Planck Institute for Demographic Research Konrad-Zuse Str. 1, D-18057 Rostock · GERMANY www.demographic-research.org

DEMOGRAPHIC RESEARCH

VOLUME 22, ARTICLE 34, PAGES 1057-1096

PUBLISHED 22 JUNE 2010

http://www.demographic-research.org/Volumes/Vol22/34/

DOI: $10.4054 /$ DemRes.2010.22.34

Research Article

\title{
Understanding the long term effects of family policies on fertility: The diffusion of different family models in France and Germany
}

Anne Salles

Clémentine Rossier

Sara Brachet

(C) 2010 Anne Salles, Clémentine Rossier \& Sara Brachet.

This open-access work is published under the terms of the Creative Commons Attribution NonCommercial License 2.0 Germany, which permits use, reproduction \& distribution in any medium for non-commercial purposes, provided the original author(s) and source are given credit.

See http:// creativecommons.org/licenses/by-nc/2.0/de/ 


\section{Table of Contents}

1 Introduction 1058

2 Fertility, family policy and female labour force participation in $\quad 1060$

France and Western Germany

3 Data and methods 1066

3.1 Two comparable sets of in-depth interviews in France and German 1066

$\begin{array}{lll}3.2 & \text { Analysis } & 1068\end{array}$

$4 \quad$ Results: Western Germany 1068

4.1 Childless respondents 1068

4.1.1 Respondents wishing to combine work and family 1069

4.1.2 Childless respondents who prefer a stay-at-home mother 1072

4.1.3 Childless respondents who want to remain childless 1072

$\begin{array}{ll}4.2 & \text { Respondents with children } \\ \end{array}$

$5 \quad$ Results: France 1076

5.1 French respondents without children 1076

5.1.1 Childless respondents who think that mothers should to return to 1076

$\begin{array}{lll}\text { 5.1.2 Childless respondents who consider the option of parental leave } & 1078\end{array}$

5.2 French respondents with children 1078

5.2.1 Respondents with children where mothers returned to work after 1079

5.2.2 Respondents with children who opt for parental leave 1080

5.2.3 Respondents with children with a stay-at-home mother 1082

6 Discussion 1082

$\begin{array}{lll}7 & \text { Conclusion } & 1085\end{array}$

8 Acknowledgements 1086

$\begin{array}{ll}\text { References } & 1087\end{array}$

$\begin{array}{ll}\text { Annex } 1 & 1094\end{array}$

$\begin{array}{ll}\text { Annex } 2 & 1095\end{array}$ 


\title{
Understanding the long term effects of family policies on fertility: The diffusion of different family models in France and Germany
}

\author{
Anne Salles ${ }^{1}$ \\ Clémentine Rossier ${ }^{2}$ \\ Sara Brachet ${ }^{3}$
}

\begin{abstract}
European countries in which mothers are encouraged to remain in the labour market have higher fertility levels. It is difficult, however, to link specific policies to fertility increases. We hypothesize that policy changes do not affect fertility decisions in the short term as long as external childcare is not seen as an acceptable option, although policy does have an impact upon childcare attitudes in the long term. Using a comparative qualitative approach, we find that attitudes towards childcare are strikingly different in France than in Western Germany, reflecting long-standing policy orientations. Attitudes act as an intermediate variable between access to childcare and its use in both countries, and are strongly homogenous within countries.
\end{abstract}

\footnotetext{
${ }^{1}$ Université Paris - Sorbonne (Paris 4). E-mail: anne.salles@paris-sorbonne.fr

${ }^{2}$ Institut National d'Etudes Démographiques.E-mail: clementine.rossier@ined.fr

${ }^{3}$ Institut National d'Etudes Démographiques. E-mail: brachet@ined.fr
} 


\section{Introduction}

In all European countries, the actual number of children remains below the desired number of children (Goldstein, Lutz, and Testa 2003). This trend emphasizes the important obstacles to childbearing prevalent in contemporary industrialized countries. Because they reduce the cost of children, family policies are often seen as a way of encouraging family formation. Whether family policies have an impact on the number of births has, however, been a question of debate among demographers for more than twenty years.

A number of scholars have recently argued that policies which help women combine work and family (i.e. state supported parental leave and collective child care), produce better results than financial aids (McDonald 2005; Hantrais 2004; Neyer 2003; Gauthier 2007), contrasting the relatively high levels of fertility in the Nordic countries and in France with the relatively low levels of fertility in German-speaking European countries. However, it has proven difficult to link specific policy measures (even those helping women combine work and family) introduced in individual countries to durable and substantial fertility increases. In Germany, parental leave benefits were upgraded in several ways in 2007 (Spiess and Wrohlich 2008); however, that same year, the number of births increased by only $1.8 \%$, and even decreased by $1.1 \%$ in 2008 , while the total fertility rate progressed only slightly, from 1.34 children per woman in 2006 to 1.38 in 2008. Similarly, in France, parental leave benefits, initially reserved for parents who had a third birth, were extended to the second birth in 1994: this policy change resulted in increased take-up of parental leave, but its final impact on the fertility level is estimated to be small (Toulemon, Pailhé, and Rossier 2008). At the individual level, studies investigating the link between the availability of child care options and fertility outcomes have also generally failed to show a positive relationship between the two parameters. In Germany, Hank and Kreyenfeld (2003) observe no notable statistical effect of access to child care on individual fertility (see also Kreyenfeld and Hank 2000; Ette and Ruckdeschel 2007).

One way of shedding some light on this puzzle is to distinguish between the shortterm and the long-term effects of family policies on fertility. As Toulemon, Pailhé, and Rossier (2008) explain: "Measuring the impact on fertility is complex and very sensitive to the method and data used. One can measure the short-term effects of policies, whereas long-term trends are more difficult to evaluate. These long-term trends depend more on a favourable context to families than on specific family policies" (p. 541). The short-term effects of policies favouring the combination of work and family are the immediate availability of affordable pre-school child care and the possibility of taking (relatively short) parental leave without losing one's job. These measures decrease the opportunity costs of children for women, and they should thus 
increase fertility outcomes immediately, especially for women with higher educational and income levels (Becker 1981). However, we hypothesize that women and couples adopt these solutions and have more children only when they believe that external child care and a working mother are not detrimental to their child's development. In other words, we hypothesize that the fertility-increasing effects of policies supporting the family-work balance are conditional on a cultural shift, i.e. on the acceptance of the idea that mothers can resume work without harming their children. Before this cultural change occurs, even the provision of generous childcare options will not change individuals' family and work decisions overnight.

We also hypothesize that by helping women combine work and family, family policies have the potential to drive such a cultural shift over the long term. Indeed, ideological change usually occurs as follows: a few innovators show the way by adopting the new practice, in this case new forms of child care; if the innovation proves beneficial, the new attitudes towards childcare (and practices) then diffuse to some of the individuals closest to the innovators, and so on (Rossier and Bernardi 2009). This attitudinal change will take time, but once in place, individuals' attitudes towards combining work and family may become strongly anchored, and their fertility and labour market decisions may then be robust against small variations in the range or amount of available childcare options. Couples who do not have access to child care in a context friendly to working mothers may use various strategies to find child care where it is available (move, change jobs, increase father's participation, etc.), and still achieve their desired number of children and their desire for both parents to remain employed.

In short, the relationship between policies supporting the work-family balance and fertility may not be a direct one; change in fertility behaviour may be concentrated around a turning point after which most people believe that is right for mothers to work, and after which most mothers do in fact work, managing to find child care where it is available. An important aspect of this argument is that policies supporting the workfamily balance have the potential of increasing (or sustaining) not only fertility outcomes but also fertility intentions in the long term, through the mechanisms of ideological change already described. In a context in which it is easier to combine female employment and child raising, couples will begin to have more children, which in turn will increase long-term fertility intentions across society as whole.

In this paper, we explore the long-term impact of policy environments promoting the combination of work and family on individuals' representations of working mothers and external childcare, and the link between these representations, use of childcare, and fertility intentions and behaviours. We focus here on the European welfare state nations which have developed strong family policies since World War II, among which we distinguish between countries which provide childcare and parental leave programmes 
(France and the Nordic countries) and those which provide financial aid only (Germanspeaking countries) (Strohmeier 2002). In this paper, we will contrast more specifically two countries taken from these sets of nations: France and Germany, restricting ourselves to Western Germany.

In the second section of this paper, we summarize the differences in fertility trends and female labour force participation between France and Western Germany, and their widely different family policy environments. In a third section, we describe our data: in 2007, we interviewed 27 men and women aged around 30 years who grew up in a medium-sized city in France, using a recruitment strategy and interview guide comparable to that applied for a study of 35 individuals conducted in a medium-sized city in Western Germany in 2005, which was itself part of a study comparing Western and Eastern Germany (Bernardi, Keim, and Von der Lippe 2007; Bernardi, Klärner, and Von der Lippe 2008). In a fourth section, we present a typology of attitudes towards formal childcare and mothers' work in Western Germany, and relate these attitudes to fertility intentions and actual fertility. We replicate this analysis with the French data in a fifth section, before comparing in a sixth section the results across the two countries, and assessing the implications of our results in relation to our hypotheses.

\section{Fertility, family policy and female labour force participation in France and Western Germany}

With a total fertility rate (TFR) of 2.02 children per woman in 2008, France has one of the highest fertility rates in Europe, in contrast to Germany, where women had only 1.38 children on average in 2008. The mean age at birth has increased in both countries during the last few decades, and is comparable in Germany (30.0 years in 2008) and France (29.9 in 2008). The very low fertility in Western Germany seems to be due in particular to atypically high levels of childlessness compared to the rest of Europe (Dorbritz, Lengerer, and Ruckdeschel 2005; Dorbritz 2005). Although data sources are not complete and estimations vary, $21 \%$ of women aged 40 to 44 remained childless 2008 , with a larger proportion among highly educated women (Statistisches Bundesamt 2009; see also Dorbritz 2008) The high level of childlessness has led to a "polarisation" of reproduction in that country (Huinink 2002): "the family-forming-age population can be roughly sub-divided into two groups: those who live with children, and are usually married; and those who have chosen not to have children, the vast majority of whom do not marry" (Dorbritz 2008:560). This "polarisation situation" is more pronounced among couples with better professional positions and higher educational attainment. Because of a stronger connection between marriage and births in Western Germany, the share of births outside marriage, which has increased in both 
countries, is still lower there (18\% in 1999) compared to France (41\% in 1999) (Le Goff 2002). Arguably owing to the high level of childlessness (Testa and Grilli 2006), Germany is one of the rare countries in Europe where the desired number of children has fallen. According to the Generations and Gender Survey conducted in 2005 in both countries, people want 1.7 children in Germany, compared to 2.3 children in France ${ }^{4}$. However, Eurobarometer data (Testa 2006) show an increase in the personal ideal family size in Germany between 2001 and 2006 (from 1.66 to 2.17 children for males, from 1.96 to 2.24 for females), while the same data indicate that ideal family size was higher and stable in France over the period (2.31 in 2001 and 2.45 in 2006 for males, and 2.52 in 2001 and 2.59 in 2006 for females). Note that in both countries immigrants do not significantly affect the total fertility level, since migrants tend to adopt the fertility behaviour prevalent in their host country (Toulemon 2006; Milewski 2007).

State support to families is comparable in France and in Germany, so they both feature in the same group of countries in the typology established by Dorbritz and Fux (1997) on the basis of the percentage of gross national product allocated to families (see also Lengerer 2004). Belgium, Austria, Luxemburg and Denmark are also included in that group. Dorbritz and Fux distinguish two other categories: countries which allocate a lower share of GDP to family policy and support families in a selective way, such as Great Britain, Ireland, The Netherlands and Switzerland, and those countries which allocate a very low share of GDP to family policy and limit their support to poor families only, such as Spain and Italy. Similarly, both France and Germany (along with other Central Western European countries) are characterised by Esping-Andersen as corporatist regimes, with a high level of state support and a system of family benefits based on patriarchal assumptions (1990). Esping-Andersen groups the Nordic countries together: these "welfare states" have universalistic state policies that promote the independence of individuals and social equality; English-speaking countries are "liberal welfare states" promoting market-based individualism, and the southern European countries are like the corporatist nations, but with a stronger family bias.

In all other typologies, France and Germany appear in different categories. Gornick, Meyers, and Ross (1997) group France, Belgium, Denmark, Finland and Sweden together, as countries where social policies help women remain in the labour force, and contrasts them with Germany, the Netherlands, and Italy, where family policies oblige women to leave the labour force until their children go to school (see also Lewis and Ostner 1995; Gauthier 1996 for similar distinctions). Anttonen and Sipilä (1996) distinguish different types of state child care policies: the Scandinavian

\footnotetext{
${ }^{4}$ Results of the Generations and Gender Survey 2005 for men and women between 20 and 39. Kinderwünsche in Deutschland, BiB-Mitteilungen 2/2007, pp. 19-21. We found the same results for Germany in the Population Policy Acceptance Study of 2003 (Dorbritz, Lengerer, and Ruckdeschel 2005; Hoehn, Ette, and Ruckdeschel 2006). The French results were calculated by Arnaud Régnier-Loilier (INED).
} 
model (universal policies aimed at promoting gender equality); the Southern model (limited supply of state care services); France and Belgium, with extensive state support to families but no support for gender equality; Netherlands and Germany, where childcare is still provided by parents who benefit from state support schemes; and the British system, in which state help is mostly directed towards 'problem cases'. Hantrais (2004) groups the relationship between family and state into three categories. The Nordic and French-speaking countries are 'defamilialised' (strong state support for the care of family members); the English- and German-speaking countries and the Netherlands are 'partially familialised'; the Southern countries are 'familialised'. Strohmeier (2002) distinguishes family policies providing economic aid (i.e. financial aid) from those providing "ecological" aid, i.e. services in the field of child care. France, like the Nordic countries, belongs to the first group of countries with high levels of aid in both fields, whereas Germany, along the other German-speaking countries of Europe, belongs to the second group with a low level of "ecological" aids, but a high level of financial aid (see also Kaufmann et al. 2002).

French family policy has two main objectives. First, it favours the combination of work and family, by promoting the labour force participation of mothers. Several measures are specifically designed for that purpose. To begin with, parental leave allowances are only granted to women who had been working before the birth of their child. Moreover, the legal framework of parental leave encourages its beneficiaries to limit its duration. Their allowance is extended for two more months if they end their parental leave after 18-30 months to go back to work. Mothers of three or more children receive benefits that are $50 \%$ higher than the normal rate if they agree to limit their parental leave to a duration of one year (Salles 2004). Besides, part time work during parental leave is possible and even encouraged by the 2004 reform of the parental leave system. Moreover, families can receive direct and indirect benefits for formal child care from the end of maternity leave. Child care in day-care centres or by a childminder at her home or at the child's home is subsidized by the government. For the employment of a registered childminder working in her home, families receive a monthly grant, are exempted from employers' social security contributions, and can deduct part of the cost of child care from their taxable income. When the childminder works at the child's home, the parents pay only part of the employer's social security contributions and benefit from tax breaks. The number of places in day-care centres for small children is limited, however, and is unable to meet demand. The French government is aiming to create 350,000 additional places for small children in day-care centres. After three years of age, children enter the school system where the provision of school lunch and of supervised activities after school and on days when schools are closed (Wednesdays and school holidays) enables both parents to work full time. Yet on the other hand, French family policy also favours child care by the mother, especially by providing 
three years of parental leave and by offering an allowance to all stay-at-home parents for a period of three years. This highlights the ambiguity of French family policy (Thévenon 2008).

The second objective of French family policy is to promote large families. Family benefits are not paid to families with only one child, but start with the second child and increase considerably with the third. Moreover, thanks to the "family ratio" mechanism (quotient familial), the tax regime is particularly attractive for families with three or more children. The "large family card" entitles members of large families to price reductions for transport, cinema and other leisure activities. The retirement benefits of civil servants are $10 \%$ higher for parents of three children, with an extra $5 \%$ for every additional child. Moreover, civil servants who have three or more children can retire after 15 years of active service. We already mentioned that parental leave was first designed for large families, and extended to families with two children only in the mid 1990s; since 2004, parents of one child can take parental leave, but only for 6 months.

Like France, Germany devotes a large share of its GDP to family policy, but the funds are allocated very differently. To begin with, the German policy framework does not favour the combination of work and family. There are two reasons for this. First, parental leave allows mothers to withdraw from the labour market for up to three years per child; parental leave is granted even to mothers who have never worked before (note that the parental allowance is paid for only 14 months since 1 January 2007, but can be received at a $50 \%$ rate for 28 months) ${ }^{5}$. Second, there is little external child care provision in Germany, especially in the Western part of the country, and existing facilities are less heavily subsidized than in France. In Western Germany in 2009, only $5.1 \%$ of children under three were looked after in day care centres or by a childminder during the day, i.e. for a minimum of 7 hours a day (Statistisches Bundesamt 2009). The school system is not adapted to dual-earner families: kindergartens which are attended by $90 \%$ of children aged 3-6 in Western Germany generally open in the morning only. Only $17.3 \%$ of children in this age range go to kindergarten for the whole day in Western Germany ${ }^{6}$. Primary and secondary schools also take children only for part of the day, according to timetables which are rarely the same from one day to the next (Honekamp 2008). In 2006, the German government extended the range of tax deductions for child care costs: working parents can now deduct from their taxable income two thirds of the costs of a childminder at home, up to a maximum of $4000 €$ per year for a child below 14 (Fagnani, Math, and Meilland 2009). Because of the lack of day care, mothers often have no other choice until recently but to withdraw from the

\footnotetext{
${ }^{5}$ Whereas parental allowance is limited to the first 12 or 14 months following the child's birth, parents may still demand a parental leave up to three years (Bundesministerium für Familie, Senioren, Frauen und Jugend 2009).

${ }^{6}$ Statistisches Bundesamt (2008). Pressemitteilung Nr.070, 22.02.2008, http://www.destatis.de/jetspeed/ portal/cms/Sites/destatis/Internet/DE/Presse/pm/2008/02/PD08_070_225.psml
} 
labour market until their child went to kindergarten, and to take up part time work afterwards. Part time work is favoured by three measures. Married couples are less heavily taxed if the salaries of the husband and wife are significantly different; this is generally the case when the wife works part time. Moreover, in companies with at least 15 employees, every employee is entitled to ask for part time working hours. Finally, part-time jobs with limited working hours and a salary of not more than $400 €$ a month (so-called mini-jobs, a German specificity) are exempt from taxes and social contributions: mothers often opt for this type of part-time work, at the risk of losing their professional skills (Dearing et al. 2007; Lestrade 2004).

In contrast to the focus of French family policy on large families, the German family policy does not take account of family size. For example, child benefits are higher than in France and are paid from the first child. Families are entitled to a parental leave of three years, also from the first child.The two family policies can be contrasted on one more point. The French family policy favours high salaries as the "family ratio" is proportional to income, so the richest families benefit the most (Thévenon 2008). German family policy is more even-handed in this regard. Some measures benefit poor families. For example, a low-income dual-earner family receives an allowance of $140 €$ a month until the $3^{\text {rd }}$ birthday of their child, while high-income dual-earner families are penalized by the tax ratio of dual-earner married couples. However, other measures are more beneficial for high-income earners, like the tax deductions for child care costs (Luci 2010).

This difference can be understood in the light of Germany's and France's respective histories. After WWII, German governments were intent on stressing their difference both with respect to the national socialist past and the communist regime of Eastern Germany. They decided on two objectives. The first was to give priority to the individual over society, which implies respecting individual choices and guaranteeing individual liberty. The second was to restore the private dimension of family life, in other words to shield children from any outside influence. Consequently, all successive German governments limited their intervention into family affairs as much as possible and tended to favour exclusive child care by mothers. Another reason for this choice is the influence of the church on politics in Germany, at least until the 1980s (Fagnani 1992; Pinl 2003; Salles 2006).

In France, the promotion of family policies dates back to the late $19^{\text {th }}$ century and is linked to the efforts on the part of an early centralized state to counterbalance the power of the church by investing in the private sphere. These efforts were fuelled by the emergence of pronatalist movements following successive defeats by Germany. "The family policy that was finally implemented after the Second World War was a compromise between a Catholic vision of the family and more progressive ideals of social equality. The policy was based on the male breadwinner and female caregiver 
pattern, but the development of kindergartens, introduced at the same time, was meant to promote equal opportunities among French children. [...] From the 1930s to the 1960s, the French family policy reinforced the pattern of the non-working mother, because family allowance was paid from the first child onwards when the woman did not work. The policy was adapted in the 1980s to accommodate the massive influx of women onto the labour market. Collective and private care arrangements were developed for children under three, which helped women to reconcile family and work with almost no increase in men's participation in child care. This long history of considering family policy enabled the government to react swiftly to women's entry into the labour force by designing new policy measures" (Toulemon, Pailhé, and Rossier 2008:536).

As a result of these contrasting family policies, female labour force participation differs in France and Germany. The labour force participation rate of mothers is higher in France than in Germany whatever the number and the age of the children: altogether, $36.1 \%$ of German mothers and $53.7 \%$ of French mothers with at least one child under the age of twelve work full time. Moreover, most German mothers work part time, whereas French mothers favour full time work (see Graph 1). The differences are even more striking when only Western Germany is considered (not shown): less than $10 \%$ of Western German mothers with one child under three are in full-time work (Fagnani and Math 2008; Fagnani, Math, and Meilland 2009).

\section{Graph 1: Labour force participation of mothers aged 20-49 by number of children under the age of 12, France and Germany}

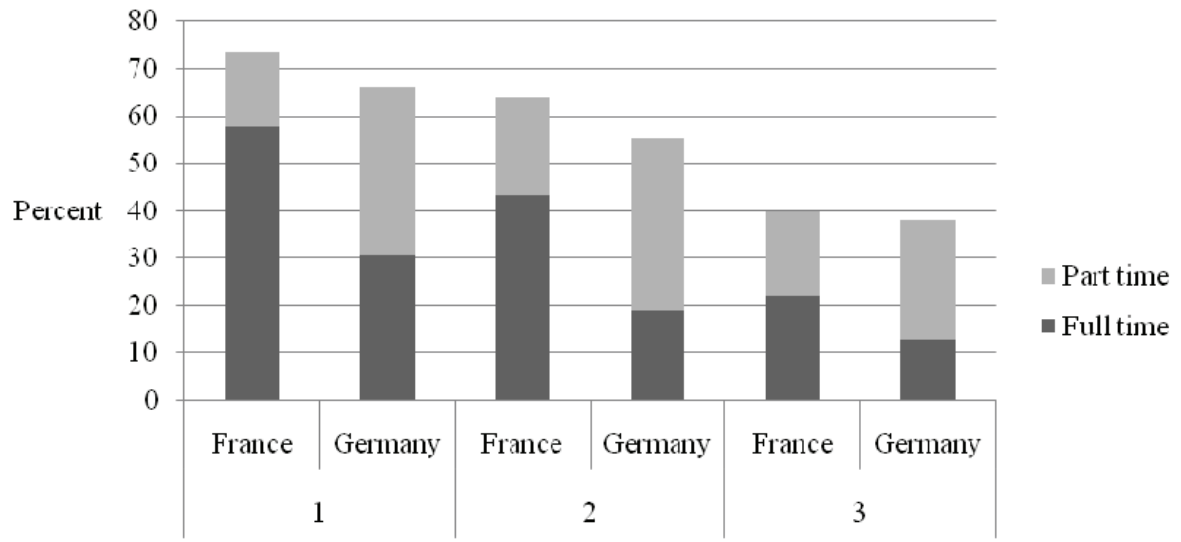

Number of children under the age of 12

Source: Calculated from EUROSTAT data, News Release, 4/2005; Fagnani, Math, and Meilland 2009. 
As already mentioned, since it is difficult for mothers to work in Germany, women with higher level jobs and higher levels of education tend more often to remain childless in that context; moreover, when they do have children, their level of education is not a factor of higher fertility once their partner's educational attainment is taken into account (Kreyenfeld 2002; Koeppen 2006; Schroder and Bruderl 2008). By contrast, in France, while women with higher educational attainment and higher socio-occupational status are somewhat less likely to have children, they are more likely to have three children once they start childbearing, so that altogether, there is a positive effect of women's education and occupational status on fertility (Ekert-Jaffé et al. 2002), as is the case in several Nordic countries (Hoem and Hoem 1989; Kravdal 1992; Hoem 1993; Oláh 1996).

\section{Data and methods}

\subsection{Two comparable sets of in-depth interviews in France and Germany}

To study individual representations of work and family, and their relationship to fertility intentions and outcomes in two different family policy contexts, we used data from a comparable qualitative study conducted by the Max Planck Institute of Rostock (Germany) and by the Institut National d'Etudes Démographiques (INED, France) on the determinants of entry into parenthood. The data comprise 62 semi-structured interviews, of which 35 were conducted in 2004-05 with people who grew up in a Western German town (Lübeck), and 27 were conducted in 2006-07 with people who grew up in a French town (Poitiers). The respondents are between 28 and 37 years of age at the time of the interview, which are the peak childbearing years in both countries. The sample includes both men and women, and people with and without children. See Table 1.

Both Lübeck and Poitiers are university towns of comparable size, close to large city centres (Hamburg for Lübeck, and Paris for Poitiers). The persons selected for the interview all attended high school in these towns. The main purpose of the study was to investigate the impact of social network interactions on fertility decisions: respondents were chosen from among people who went to the same high schools to control for primary socialization, an issue which is important when studying secondary socialization (i.e. social influence in social networks) (Bernardi, Keim, and Von der Lippe 2007). Only people still living in or around the two towns or close by (in Hamburg or Paris) were selected. Respondents were contacted via Internet sites of alumni or via the snowball technique (contacts obtained from prior respondents). The method of sample selection focused mainly on the middle class, especially in the 
Western German sample. The respondents' educational level is comparable in both data sets, ranging from medium to high. However, in the French sample, we made an effort to add some individuals without a high school diploma, and we interviewed in Paris the most career oriented individuals among those who grew up in Poitiers. Hamburg on the other hand is not the main centre of attraction for the highly qualified and ambitious young people from Lübeck, who have a tendency to move to the cities in the South of Germany, so the German sample contains few career oriented individuals.

Table 1: The French and the Western German samples

\begin{tabular}{lcc}
\hline & Poitiers(France) & Lübeck(Western Germany) \\
\hline TOTAL SAMPLE & 27 & 35 \\
Men & 12 & 15 \\
Women & 14 & 20 \\
PARITY & & \\
Childless & 13 & 24 \\
One child & 6 & 9 \\
Two children & 7 & 2 \\
Three children & 1 & 0 \\
EDUCATIONAL LEVEL & & \\
Low & 2 & 0 \\
Medium & 13 & 12 \\
High & 12 & 23 \\
MARITAL STATUS & & \\
Married & 7 & 14 \\
Cohabiting & 8 & 6 \\
Single & 11 & 14 \\
Engaged & 0 & 1 \\
Divorced/separated & 1 & 0 \\
\hline
\end{tabular}

The interviews were semi-structured, and respondents were asked to express themselves on the following issues: professional, residential, marital and reproductive history, quality of the conjugal relationship and future projects (if any), family background and current social network, representations of gender roles and division of tasks within the couple, representations of the meaning of children and of the conditions for having children, evolution of fertility intentions over the life cycle, knowledge about different childcare options and effective childcare arrangements (on this point the French interview guide was adapted to the French context), fertility behaviours and representations in respondents' social networks, and finally, perceptions of their future. Interviews were recorded and transcribed, and names have been changed. 


\subsection{Analysis}

All French and Western German interviews were encoded on the computer program Nvivo 7, using a thematic classification. This encoding prepared the content of the interview for theme-by-theme analysis, and allowed analysts to go back rapidly to certain sections of the interviews or quotes. Each French and Western German interview was summarized in a "portrait" based on a thematic grid (childhood, occupational history, marital history, fertility intentions and outcomes, child care: attitudes and practices, current social network, gender relations, exchanges in social network about childbearing and rearing), and the portraits were illustrated by quotes. By comparing the portraits (going back to the interviews when necessary) we established a typology of representations and practices of mothers' work and childcare. The typology was defined separately for France and Germany, by one co-author fluent in German for the German data set, and one co-author fluent in French for the French data set. Putting the two typologies together, a third and larger typology was created which could accommodate all the types identified in both countries. We included the respondent's educational level as part of the description of each type which emerged from the data.

In a second step, we linked individuals' attitudes towards work and family to fertility intentions and behaviours. We analysed the data first for childless respondents, focusing on the impact of representations of work, family and childcare on fertility intentions. We then extended the analysis to respondents with children to study the impact of childcare representations and practices on fertility outcomes as compared to initial intentions, and their effect on further fertility plans.

\section{Results: Western Germany}

\subsection{Childless respondents}

We first analysed in detail the attitudes towards work and family of the childless respondents in the Lübeck sample (25 respondents). See Table 2. 
Table 2: Typology of attitudes of childless respondents towards work and family, Western Germany

\begin{tabular}{cccc}
\hline \multicolumn{2}{c}{ Wish to combine work and family } & \multicolumn{2}{c}{ Do not wish to combine work and family } \\
\hline Only maternity leave & Parental leave & Preference for children & Preference for work \\
\hline Christin & Anja & Amelie & Jan \\
& Katrin & Arno & Julia \\
& Martina & Susanne & Maike \\
& Matthias & & Miriam \\
Nina & & \\
Paul & & \\
Ralf & & \\
Stefan & & \\
& Thomas & & \\
Claudia & \\
Jürgen & \\
Paula & \\
Ulla & \\
Wiebke & \\
Lars & \\
Martin & \\
\hline
\end{tabular}

\subsubsection{Respondents wishing to combine work and family}

Among the childless respondents, most (16) respondents wish to combine work and family. This group includes both women and men, with varying educational levels and conjugal situations. Only one woman is thinking about going back to work directly after maternity leave (Christin), but she refers to this course of action as one option out of two; she would in fact prefer to take a one-year parental leave. All the others expect the mothers to take parental leave after the birth of their future child (one year for six respondents, longer for eight respondents, and not specified for two respondents). Whether they prefer long or a short parental leave, all think that it should be followed by part time work (usually a few hours a week) and subsequently, in some cases, by full time employment once the children have grown up.

All these respondents share a highly gendered vision of parental tasks. The idea that somebody other than the mother could take the parental leave never even crossed some respondents' minds. This division of tasks is often justified by biological arguments: women are not like men; they have a specific role to play in respect to the child. A baby "has instincts" and that is why the mother is "required in the first place" 
(Stefan) $)^{7}$. Certain women point to pregnancy and breast-feeding in order to justify the fact that mothers and not fathers go on parental leave. "Why, he could breast-feed baby while he's at it; no, really, I think this is out of the question for us" (Paula). Some respondents also refer to the importance of men's continuous presence in the workforce: "Employers often have to deal with the consequences of women giving up work. Now they also have to compensate for the parental leave of men. This is certainly not the dream of an employer" (Matthias). Matthias adds that his employer would be shocked if he took parental leave: pressure on men's full time employment comes from all sides.

Only one person does not support the idea that mothers play a special role in childrearing: Jürgen confirms that he is willing to take parental leave if his wife has a higher salary than himself. His own mother worked while he was a child, and he has not suffered from that situation.

"Both parents were working or are working. That means, I very soon became independent, had my own key, was a so-called "latchkey child". But I received everything I wanted. Not from a financial, material point of view, but I got what I needed. I think, it was Ok. My parents were always there, I could always go to them, when I had problems at school." (Jürgen)

All the respondents in this group point out that it is important for mothers to return to work. A first argument mentioned is financial: mothers must contribute to the family income in order to maintain its living standard. But usually, financial reasons are not described as the most important: the main point of part time work seems rather to help women keep their financial independence by earning some pocket money (Christin, Martin). Women also want to work for their personal fulfilment. According to certain respondents, staying at home leads to intellectual frustration, boredom, fatigue and isolation (Claudia, Ralf). These women say that they like their work and that they do not want to lose contact with their professional universe (Anja). However mothers should only work when the child is in kindergarten or at school, because mothers want to be there for their children.

"I really want to see my child grow up, at least until he goes to school. Having him around me in the afternoon, building a real relationship, because the three first years are the most important ones. But after that, you also have to reinforce this link. That somebody is at home when I get there, that I can count on that. Maybe Mummy isn't there two afternoons per week, but the rest of the time she is there. And I think this is important, for me too, this is very important." (Nina)

In this mindset, child care is seen as almost wholly assumed by mothers. Paula says that she will bear "the essential responsibility [of child care] for at least eighteen years." External child care (grand-parents or paid child care) is not seen as an option

\footnotetext{
${ }^{7}$ The age, marital status, number of children and occupational status of each respondent is described in Annex
} 1 (German respondents) and Annex 2 (French respondents). 
for extended periods of time. Grand-parents are only considered as an extra source of care. Most respondents reject the principle of external child care (childminder or childcare centres). The main reason invoked here is that children are the responsibility of parents, who are solely in charge of their education. To entrust one's child to somebody else, above all to somebody who does not belong to the family, means that you want to get rid of your child and that you do not fulfil your duties as a parent.

As a result, these women, if they want children, must give up the idea of a professional career. This is very clear in the case of Anja. When asked about her future, she sees two possibilities: either she has a career and no children, or she has children and must forego the career she desires. Similarly, Christin gave up the idea of pursuing a doctoral thesis because it would have prevented her from having a child before her $35^{\text {th }}$ birthday. Instead, Christin explains: "My plan was to study, to get a job where I could work part time, in order to take care of my children and nevertheless earn my own money."

Certain respondents even think that women who want children should give up the idea of going to university and follow a simple vocational training course instead. Britta voluntarily gave up going to university because she knew that she wanted to have a family later on. "I always thought, one day it's family, and in this case it isn't worth studying and afterwards not being able to work in your job." By contrast, Julia, who is a dental assistant, points out that she has the perfect job for a mother; but she does not want to have children. As a result, she thinks that she has made the wrong choice and she wants to get a high school certificate in order to start university studies.

In this mindset, where women are the primary care givers of their children, and work a few hours a week, during school hours, to provide a back-up income to the family or to earn some pocket money, men are seen as the main providers of the family income. This fact is underlined by many respondents (Katrin, Paul, Jürgen, Martin): "When all is said and done, he must be able to provide for his family" (Martin). Several women establish a link between the fact that they could not have children and the income of their husband or partner.

In this first group of respondents, most express fertility intentions of around two children. Two respondents wish to have one or two children (Ulla, Paul), four would like to have two or three children (Christin, Wiebke, Matthias, Martin) and all others mention exactly two children. There is no difference in the fertility intentions of respondents who prefer to take up to one year parental leave and those who prefer a longer career break. 


\subsubsection{Childless respondents who prefer a stay-at-home mother}

In this second group, we placed four childless respondents who are in favour of women staying at home to raise a family (Arno, Amelie, Susanne, Ulrich). None of these respondents is currently in a cohabiting relationship. Most of them have a university degree; one is still a student, and the three others have intermediate level jobs: educator, journalist, in the communication department of a firm, insurance agent.

Different personal histories explain this choice: in the case of Ulrich, he had a positive experience of a stay-at-home mother when he was a boy; in the case of Arno, it is exactly the other way round: both his parents went to work and he was looked after by his grand-parents, which he resented. As for Amelie, she is jobless right now following her cancer treatment and she says she is satisfied with her life as it is.

The positions expressed by these respondents are close to those of the previous group. Their wish to be a stay-at-home mother / have a stay-at-home wife implies that the family earnings depend totally on one person only, i.e. on the father. For example, Susanne complains about her former boyfriend, because he did not earn enough money to sustain a family. However, the respondents in this category do not expect their wish to come true: these (middle class) respondents think they cannot forgo the mothers' income.

"Well, I rather expect that both are obliged to work. That is what happened unfortunately when I was a child. I lived with my grand-parents. The aim would be that only one goes to work. Whether this is possible remains to be seen." (Arno)

Fertility intentions among these respondents are higher than in the last group: women's plans to give up work altogether are accompanied by more ambitious plans in terms of family formation. These respondents all say they would like to have two or three children, with the exception of Arno whose intentions of fathering a child do not appear to be certain.

\subsubsection{Childless respondents who want to remain childless}

This last group comprises four respondents who do not wish to have children at all: one man and three women of varying educational levels and conjugal situations. The positions in this category are very similar to those expressed by respondents in the previous category. The case of Jan excepted (who does not express any opinion about child care and gender roles), these three women are all convinced that you have to give all your time to a child if you have one. All three of them totally reject all and any mode of external child care, that of grand-parents included. 
"And I also think, if somebody decides to have children, for me it's either children or a career. Both together, that doesn't fit. There is always something or somebody who doesn't get their share. And then I think that it shouldn't be the child who is disadvantaged but the career. And then, well, I think that if somebody decides to have children, and when later they are at school or in kindergarten, and that then if you have the time when they are away, you could go to work, but when the child comes back from school or from kindergarten at midday, I have to be there. I really think that I am that old-fashioned. That really is my opinion. In my opinion it is a bad thing to give the child the whole day long to a nanny or to an au-pair girl or to kindergarten; everything really must be organized. I don't need to have a child, if I'm unable to take care of it. It's me who is responsible for bringing up the child, and not any kindergarten teacher or a childminder or an au-pair girl or the grandma or what not. This is my job, that is, mine and that of my partner. And I think, I don't know, somehow real bad. These women who want to fulfil themselves, but who also want to have children..." (Julia)

This position is also highlighted by Claudia, who is not sure that she wants a child precisely because she does not want to take care of him/her full time for three years.

A: Even if it sounds horrid, I think I would never stop working. Perhaps I'd do it for a year or even two, but I'm afraid I'd be horribly unhappy if I were at home.

Q: Why do you think that it sounds terrible?

A: Well, we talk about it with others. I think it's terrible if I say something like that. (Claudia)

Claudia's reaction underlines the connection between having children and staying at home: Parental leave followed by part time work is seen as the only possible combination in Western Germany. It also shows the importance of social pressure around this issue in Western Germany.

Even if these women see career and children as mutually exclusive, none of them gives up children for career reasons. Their (intermediate level) job is not particularly important in their eyes. Nadia is not satisfied with her job, neither is Julia, for that matter, she wants to find another one. However, all three women associate a child with the idea of restrictions, of limitations that they find intolerable: with children, they will lose freedom, financial freedom being an important aspect mentioned.

"I don't want to give up my life. And I would have to do so, if I had a child. With my [ex] boyfriend, I could only have a child if I completely stopped working for three years. No, staying at home, changing nappies and describing in the evening what our child did that day... no, I can't. And it's alright. They [mothers] speak about their children all the time. It's a full time job and I would depend financially on my husband; I couldn't work during the first three years, because I don't know who would look after my child." (Julia) 
To summarize, respondents in all three groups think that working mothers are bad for children. What differs among the groups is that women's employment is seen as positive, if limited to hours when children are at school, in the first group; women's work is seen as unfortunately likely to be necessary for financial reasons in the second group who would prefer stay-at-home mothers; finally, the (financial) sacrifices associated with a child seem to be too heavy for respondents in the last group, who thus wish to remain childless.

\subsection{Respondents with children}

Let us now apply the same typology to the German respondents who have children: eight have one child and two of them have two children (Bärbel, Tobias). None of the mothers in this group returned to work immediately after maternity leave. And none of them decided to give up working, so that they are all in the same category: "wish to combine work and family after a parental leave". The respondents in our sample chose a break of one year (three respondents) or more (seven respondents).

The attitudes towards work and family of all these respondents are similar to those of childless people who wish to take parental leave followed by part time work. With the exception of Franziska (who shared her parental leave with her husband), women are the ones who stop working. The reasons invoked to justify this choice are the same as those mentioned by the childless respondents (biological differences, supporting men's participation in the labour force). Additional reasons are mentioned: the difference in salaries between men and women, and the hostility shown towards mothers in the workplace. On the latter point, respondents do not consider the negative attitudes of employers as a surprise, and they even seem to support it to a certain extent. After a recruitment interview Melanie was hired by the custom's service in Hamburg. But she refused the job, saying: "It wouldn't be fair; I am pregnant."

The return to work of mothers is based on the same arguments as those mentioned by the childless respondents: financial reasons and a feeling of independence and confidence through their job (Markus, Melanie). Among the ten families, only four of the mothers are actually working at the time of the interview (they are working for 5 to 16 hours a week with the exception of Franziska who is working full time: she is training to become a teacher). These women earn between 400 and 1000 euros a month, whereas men are earning much more money.

Recourse to external child care is very limited in all these families. Out of the ten couples with at least one child, three are using external child care at the time of the interview. In two families, the children are looked after by their grand-parents (on average four days a month in both families). Child care by grand-parents is obviously 
only "extra" child care, with mothers assuming the bulk of child care in all families. Melanie is the only respondent in this category whose son is looked after by a childminder because she and her husband are postal workers and they go to work very early in the morning: the childminder takes care of their son in the morning until kindergarten opens at 6 o'clock; the mother fetches her son at midday, and will do so until he goes to school.

The fertility intentions of people in this group do not depend on the length of parental leave taken. Although these respondents initially wanted the same number of children as our childless respondents (about two), they are currently revising their fertility intentions downwards. Only four respondents out of ten have realized or still wish to realize their initial fertility intentions (two children). Five families are thinking about foregoing a second child. And one family gave up plans for a third and fourth child (Bärbel). With the exception of Melanie, who was unable to have a second child for medical reasons, it is always men who are unwilling to have more than one child (Britta's husband, Markus, Tilman, Ozan). Most of the time, the women would prefer to have a second one. Why are fertility intentions revised downwards? Most of these families are frustrated by the difficulties of combining work and family. Bärbel points out that they gave up the idea of a third and fourth child because of the lack of formal child care in Western Germany. "If there were more day-nurseries, there would be more children [in Germany]. (...) With two children you are out of work for six years. And then, it becomes very very hard." Tilman said that the two years following the birth of their son were very hard and stressful. His wife stopped working to take care of their son, but she became ill, and nobody helped them; he regrets in particular that the child's grand-parents could not take care of him. As a consequence, this couple will think twice before having a second child. Ozan would like his wife to work; however, because of the cost of child care, they will probably wait until their son goes to kindergarten; another child would delay his wife's return to work, so that they can imagine not having a second child. Markus was preparing an exam in the evenings while working full time at the time of the birth of their son; even if his wife took a parental leave of one year, it would be quite hard for him to concentrate with a second baby at home. For Britta's husband, who was jobless when they had their first child, the decision to have a second child will depend on his financial situation. 


\section{Results: France}

\subsection{French respondents without children}

As in the previous analysis, we first analyzed the attitudes towards work and family of respondents without children in the Poitiers sample (eight respondents) ${ }^{8}$. Most of them (six respondents) favour the mother's return to work right after maternity leave, one respondent would consider taking one year of parental leave, and one is undecided between the two solutions.

\subsubsection{Childless respondents who think that mothers should return to work after maternity leave}

Respondents in this group (two men and four women, of varied educational level and conjugal situations) favour a quick return to work by the mother immediately after maternity leave. All women seem attached to their job, but for different reasons. For example, Sylvie is career-oriented and has professional ambitions which she wants to realize before having a child. Karine and Ariane mainly appreciate the opportunity for socialization provided by the work environment. Benoît's girlfriend fulfils her passion for the theatre by being an actor (like himself).

All these respondents believe in the combination of work and family: to them, it is possible and even preferable for mothers with young children to remain at work. They believe that mothers' professional situation can easily be combined with family responsibilities. "I want to stay employed and since the two (maternity and employment) can be combined, I just want to stay employed" (Karine). However, most women are ready to make some professional changes in order to spend more time at home, like taking up part time work. Sylvie is the only one who does not imagine any work changes as a result of the birth.

In order to combine work and family, formal external day care for their future children is widely accepted and appreciated by all these respondents. Having one's family close by is also seen as easing the burden of childrearing, because they can provide back-up to cope with unexpected changes in routine. Benoit is the only respondent who feels that he and his partner will be able to take care of their future child without external childcare, maybe with some help from the grand-parents or an occasional baby-sitter, since Benoit and his partner only work in the evening, and not

\footnotetext{
${ }^{8}$ Five cases (Patrick, Fabien, Franck, David and Justine) which did not contain enough data on the combination of work and family were excluded from the analysis, family formation being still a distant project for these respondents.
} 
often both parents at the same time. He is the only one who seems to value childrearing by the parents themselves; he is also the only respondent in this group who suffered a traumatic childhood (his mother had a mental health problem):

"It is better for the child but it is also better for the father. The first years are very, very important, the bond which will be created with the child. To see him just in the evening before he goes to sleep and a little bit in the morning, that is not good, that is not enough. No, I really want to take care of him".

For most of these respondents, women taking parental leave seems to be associated with an inegalitarian way of living. Benoît cannot even imagine asking his girlfriend to stop working to take care of their child: "That seems a little bit old fashioned to me. She has been struggling for years to be an actress. That's her life goal". Respondents in this group also seem to favour and value an equal share of parental tasks, without any major distinction between the mother and the father. The father's participation is considered as normal "Childrearing is the business of both of us. The child, anyway, is made by both of us" (Benoît). Hélène goes as far as not wanting to breastfeed her child, to avoid the exclusion of the father:

"For example I don't think I would breast-feed (...) because during two or three months, the father has a secondary role. I think that the relationship is so privileged, and the link is so strong during breast feeding that...[...] As soon as possible, it is necessary to include him in this relation, it is really necessary to make a three-way relationship."

Ariane stands clearly apart in this group. Although she approves of external childcare, she has traditional opinions about sharing parental and domestic responsibilities. Her refusal to stop working temporarily to take care of her children seems mainly related to financial reasons in her case.

"To have a working mother also helps to cut the umbilical cord between the mother and the child and to let him grow up, be independent. At the same time we do not really have the choice, given that two salaries are needed to live decently unless the husband really has a very good salary, most of the women have to work. But anyway, I could not do imagine giving up the social life, the contacts we can have with people through the work". (Ariane)

In this group, respondents want about two children, but two seems to be the maximum (except for Ariane); some talk about one or two children. Those who want two children mention that they do not want to have a single child.

"To bring up one child, to educate one, that is enough I find. But anyway, for the child's well-being, if he is alone I'm afraid that he would feel a little bit lonely. Two children I think that it is really enough. It is a good balance. But not more than two. I do not imagine myself with 15 children. If I manage to have one... Maybe two." (Hélène) 
The family model valued by these respondents is a model with no gendered role specialization, which means equal work opportunities for both parents and equal parental investment for mothers and fathers.

\subsubsection{Childless respondents who consider the option of parental leave}

Among the French childless respondents, only one woman, Elise, plans to take parental leave (and Alice hesitates).Unlike the respondents in the group above, who do not want to take parental leave, Elise is ready to give up a lot when they decide to have a child. She likes her job (she is a pharmacist), but gender equality does not seem very important to her. She imagines a family where the mother's and the father's roles are clearly differentiated: the father represents authority and the mother affection and care. She explains that this specialization is natural, because "there are some tasks that men are not able to do". However, Elise would not like to stop working totally, neither would she accept to do all the housework. Elise wants to have two children, but not right now, rather in two or three years.

\subsection{French respondents with children}

Moving now to French respondents with children (14 individuals), we see (Table 3) that women returned to work right after maternity leave in eight families, while parental leave is used or planned (for the next child) in five families, and that one respondent has a wife who stayed at home to look after the children.

Table 3: Typology of attitudes towards work and family of respondents with children, France

\begin{tabular}{ccc}
\hline \multicolumn{2}{c}{ Wish to combine work and family } & Do not wish to combine work and family \\
\hline Only maternity leave & Parental leave & Preference for children \\
\hline Marie & Valentine & Eric \\
Sandrine & Thierry & \\
Dominique & Sylvain & \\
Camille & Anne Sophie & \\
Amandine & Sofia & \\
Sammy & & \\
Etienne & & \\
Damien & & \\
\hline
\end{tabular}




\subsubsection{Respondents with children where mothers returned to work after maternity leave}

Respondents in the group are of varied educational level, all in stable conjugal relationships, four have one child and four have two children. The birth of the first child did not change these women's job situations: they all went back to work after maternity leave and continued to work full time (Camille is the only mother who adopted part time work ( $80 \%$ part-time) after the birth of their first son).

As the arrival of the child often implies new constraints, about half of these couples have found an arrangement based on the father's participation. For example, Marie's partner covers the child care hours in the morning and in the evening. Sammy has to leave work earlier to pick up his children from the child care centre. These respondents experience, to different degrees, equal parenthood, which means almost equal investment for both parents and almost no role specialization.

"I think that there is nothing that... What could I do alone with the children that Nico has never done? No I see absolutely nothing. Because whether it is cooking, painting, some Plasticine, or reading a story before they go to bed or having the bath, or working in the garden... all these things that I do, he does too" (Camille)

The other families in this group experience less equalitarian parenthood, but both partners value women's work nonetheless. For example, Sandrine complains about the unequal sharing of domestic tasks; parental leave or part time work could have been a way to lighten the burden, but she does not want to consider these solutions.

"No, I had to work. For me I had to work. And financially, it is true that it is important too. But it is mainly my personal choice. To stay at home, it was not possible, by the end of three months I just had to get out. I'm not made to stay at home... Maybe I could accept a half-time job, because when you have a child, you have lots of activities (...). But anyway, I'm not sure it would last for long. I need to go out." (Sandrine)

For these respondents (like childless respondents who do not plan to take parental leave) investing in parental tasks via parental leave is seen as "doing nothing." Likewise, full time work directly after maternal leave is not considered as incompatible with the child's well-being. They all have very positive experiences of external child care, as a source of social stimulation for their child, whether they choose a day care centre or a childminder. Sammy appreciates the social and ethnic mix in the day care services:

"I wanted them to be with other children... and I don't know how to say it... I wanted them to be in contact with other people, other nationalities and not in a small neighbourhood with only respectable children from good families." (Sammy)

Marie is living in the countryside and could not find a day care centre, which was

her first option. Her child is staying with a childminder in the neighbourhood and she is 
entirely satisfied with this solution. The most important thing for Marie was to ensure that her child spends time with other children.

"It's good for Lucas also, because all alone that would be a bit boring. Because at home he is kind of little king. He can get whatever he wants, we are at his beck and call (...) At the childminder's, if he's hungry maybe he has to wait because the other girl is eating. He learns to be patient. And if there is a toy that they both want to have, well he deals with the problem himself." (Marie)

Amandine is the only one in this group to show some regrets about her rapid return to work (but note that she has a demanding job in the private sector, that her husband travels a lot, and that they live far away from their families):

"Our experience with Simon is that, in fact, we found that he was too small, because he started with the childminder and I returned to work immediately after, so he was two and a half months old and I think that he was too small. I think that I would have liked to stay home at least for six months (...) so that he could build up his strength.(...). I have maybe a few regrets about breast-feeding too because I didn't breast-feed for long enough in fact, because I stopped when I returned to work because it really isn't easy to breast-feed and to work. " (Amandine)

Fertility intentions among these respondents centre around two children, like childless respondents in the same category. Sandrine is the only one who could be happy with just one (she is thinking about not having a second child), and Camille wants at least three.

\subsubsection{Respondents with children who opt for parental leave}

Five of the French respondents with children have taken or are thinking of taking parental leave; two have one child, two have two children, and one has three. Respondents in this group are characterized by the women's low level of labour force participation. For example, Sofia, who is an immigrant's child, has a university degree in psychology, but never found a job matching her qualifications, and works in small jobs in associations; her partner works in a video store. Anne Sophie, whose partner is a construction worker, had her children soon after obtaining her high school certificate, and worked only for a short time as an assistant in a day care center for children.

The division of parental and domestic tasks is unequal in most of these families. For example Anne-Sophie, who has not worked since the birth of her first child, does almost all the parental and domestic work, which she sees as normal.

"Let's say that when they are babies, Loïc doesn't really take care of them ...So who gets up in the night? It's me. Who gives the baby its bottle? It's me. Even the bath, 
it's me (...) But later on, let's say from one and a half, two years, he thinks the child becomes interesting" (Anne-Sophie)

Sylvain appears to be an exception in this group. He belongs to the small group of "new fathers", since he is actively involved in his children's upbringing and in all domestic tasks; his wife will use parental leave only for their third child, and he would have liked to take it himself, except that he earns more than his wife.

For all these respondents, external child care is considered as a necessary and positive complement to parenthood. They value in external childcare things like collective learning, socialization outside the home, learning from others and new and different activities for the children.

"Because they have infrastructures which provide more things than a person who works at her home. And the collective aspect, the socialization, now Lilou, you can leave her with anybody. Well, she's not afraid, she is sociable, she gives kisses, she gives cuddles ... That's it. It is this aspect that is very important for me" (Thierry)

Two of these respondents, Valentine and Sofia, are less enthusiastic about external childcare, although not at all opposed to it. See for example the discourse of Sofia, who wanted a day care centre after the end of her parental leave, but could only find a childminder, with whom she was not satisfied.

"The kids are eating all day long in front of the TV and I don't want that for my daughter. Besides, my daughter likes to eat, she was not fat but she was a little bit plump and she wouldn't stop eating all day long. I don't like that, even if she was thin, I wouldn't want my daughter to be brought up that way. I wanted activities for her, for her to go out and not eat between meals. Just normal things (...) But she (the childminder) ignored what I said. So I preferred to keep her myself." (Sofia)

When Sofia finally found a place in a day care centre for her daughter, she started to work again, but still in temporary jobs.

Fertility intentions are relatively high in this group. Sofia and Anne Sophie want to have at least three children. Thierry explains that he would like to have three or four children, but that his wife (who assumes a double burden) wants only two, so they intend to have two children. Sylvain already has three children. These couples, as opposed to couples where women do not give up work except to take maternity leave, are typically more family-oriented. These women invest less in their jobs, as motherhood is a more important investment for them. Valentine is an atypical case in this group: after working in temporary jobs and stopping work for the birth of her daughter, she has since became a manager working full time, and has separated from the father of her child; she wants only one child. 


\subsubsection{Respondents with children with a stay-at-home mother}

There is only one person in the French sample whose partner is a stay-at-home mother. Eric is a fireman. He is married and has two children. They want to have at least one more child. His wife has never worked in her life, she has very low qualifications. Although Eric wants his wife to work at some point, the traditional "Male bread-winner model", where the woman stays at home, seems to be a rational choice from both of them at the moment:

"Of course, she didn't want to work because she had no qualifications and then they (the children) were young. For the moment we will wait until they are older or there is another child, we are on stand-by. At the moment she doesn't work. I am a fireman and I look after the children at the same time, it is not so easy because sometimes I get called out on a job, sometimes you have two or three seconds to eat. We are managing at the moment. We shall wait and see". (Eric)

Eric has no experience of external child care and his opinion seems to be ambiguous. He disapproves of parents using baby-sitters to go out in the evening. $\mathrm{He}$ considers that as a parent you have to stop that kind of life which is not beneficial for the children. But he also thinks that day care centers can be a good solution, when both parents are working. He is not opposed to dual-earner families.

\section{Discussion}

In Western Germany the cultural environment remains hostile towards external child care, in particular for children under the age of three years. Parents are expected to take responsibility for caring for the child they conceived, and "non parental" care is seen as negatively affecting child development. The expression "raven mother", which means a working mother who neglects her child, remains anchored in Western German society (Onnen-Isemann 2003; Veil 2003). Mothers are expected to stop working when having a child, leading to a highly segregated division of parental tasks. Since having a child equates to the mother's withdrawal from the labour market, the opportunity costs of childbearing are very large, especially in the middle classes (where typically the wife earns quite a lot, but the husband not quite enough to forgo his wife's earnings, given the relatively high standards of living) and for career-oriented women: hence having a child often implies financial or career sacrifices for most couples in Germany. Besides, since childcare is not shared between several adults, but is the sole responsibility of the mother, the demands made on women in terms of time and effort are especially high during the first years of the child's life. And in fact, all German respondents with children complain about existing family policies, sometimes in contradiction with their 
own dislike for external child care: they highlight the problem of insufficient child care provision and the difficulties of combining work and family in general.

All the respondents in our Western German sample share this attitude. The main difference between the respondents in this sample who, let us not forget, belong largely to the middle class, is that some women or couples are not willing to make the sacrifices (here mainly financial) that are required from them in order to have children, while most are; some couples also decide not to have children so that the woman can pursue a career (but we were not able to sample them in this study based on a mediumsized city). Another difference between German respondents is that although most women or couples who want children imagine that mothers will eventually take up parttime work during the hours when the children go to school in order to enjoy the benefits of women's work (income, socialization, interest of the job), some respondents, on the other hand, prefer for mothers to stay at home while being aware that this option will not be possible due to the importance of women's income in maintaining the family's living standard. Staying at home may also make more sense for lower income couples and women with little or no job qualifications (which were not sampled here).

The situation in France is very different. Full time child care for children under the age of three in day care centres or by childminders is widely accepted. In fact, external child care is associated with positive values such as socialization and stimulating activities. Mother's employment is also associated with positive outcomes: financial input, social relations, and in some cases, the rewards of a career. For almost all respondents, external childcare while mothers work is the optimal solution for both parents and children. Couples where women are less strongly integrated in the labour market seem keener on opting for a parental leave, i.e. a longer withdrawal of mothers from the labour market, or even on choosing that the mother stays at home. The latter childcare arrangements seem linked to a less equal division of parental tasks between parents (before and after the parental leave). However, even these respondents are not hostile to non-parental child care.

In both countries, most people want two children, except in the less common cases where women invest more heavily in their maternal role (and are less keen on going back to the job market). For these respondents, three children are more often considered (couples using parental leave in France, couples with stay-at-home mothers in Germany). Statistical evidence shows that couples in the higher social categories are also more likely to want and have three children in France (Ekert-Jaffé et al. 2002); this trend does not appear in our sample, perhaps because it is composed of couples at the beginning of family formation. Two differences appear in terms of fertility intentions and outcomes in France and Germany. Because of the sacrifices associated with the birth of a child in Western Germany, a considerable percentage of people there plan not to have children at all, which is not the case in France. Secondly, some of the Western 
German couples in our sample who initially wanted two children find it difficult to achieve this goal, because of the sacrifices involved in women's long-term withdrawal from the labour market, and the absence of satisfactory alternative child care options (and one couple wanting more than two children stopped at two); this case is rarely encountered in France. Statistical evidence shows that families with one child are more numerous in France (Breton and Prioux 2008), so that our results may tend to reflect the general difficulties of having large families in Germany rather than the difficulties of having specifically two children; again, remember that our sample is relatively young. Altogether, our study confirms that policies supporting the combination of work and family seem to be one path towards higher fertility intentions and outcomes in Europe, while policies promoting the male breadwinner model seem to be a path towards lower fertility intentions and outcomes, as often noted in the macro level correlations between policy content and fertility levels.

We found that individual attitudes and practices in relation to the combination of work and family are strikingly different between the two countries. Work and maternity are experienced in parallel in France and alternately in Western Germany (Fagnani 2000; Périvier 2004). These different attitudes towards external childcare and the combination of work and family closely matches the family model and child care practices promoted by the family policies in place for many decades in each country (Fagnani 2002). This result, too, was to be expected. The majority of recent comparative studies have found a close relationship between the type of family policy and individual attitudes towards childcare, women's employment or equal gender roles (Konietzka and Kreyenfeld 2002; Sjöberg 2004; Adler and Brayfield 2006; Almqvist 2007; Kangas and Rostgaard 2007; Bernhardt et al. 2008; Henz 2008) ${ }^{9}$.

More originally, our results underline the crucial intermediary role of attitudes towards child care and working mothers in the relationship between the availability and the use of external childcare at the individual level. In France, women who want to work but cannot do so because of a lack of child care, look for it, find it, and go back to work, with fathers often helping them in achieving this goal. In Germany, women who choose to have children and who could access external childcare in order to resume work, in fact prefer to take care of their children themselves. Hence, the availability of external child care or of short parental leave is not enough to explain use or non-use: people have to be ready to use these options in order to do so.

Our second original result points to the lasting nature of attitudes towards childcare and working mothers. While these attitudes seem to be shaped over decades by policy

\footnotetext{
${ }^{9}$ Some studies did not find such a relationship, but either they did not include countries with policies supporting the work-family combination (Purr et al. 2008), or they compared Western and Eastern European countries where many factors other than the shape of policy are at play (Motiejunaite and Kravchenko 2008), or the study focused on recent policy change (Saxonberg and Sirovatka 2006).
} 
environments, they also seem to be slow to change. The homogeneity of attitudes towards child care and working mothers within each country is striking in this regard. The different sub-groups identified when analysing each country separately appear to be mere variations upon the same model when the two countries are compared side by side. Even couples with stay-at-home mothers in France believe in the benefits of organized day care, and even dual earner couples with children believe in the benefits of exclusively maternal care in Germany. Existing theories indicate that social groups where attitudes are very homogenous are characterized by strong social influence mechanisms working to maintain them; in such groups, new attitudes can emerge only slowly (Rossier and Bernardi 2009). Negative representations of external childcare will prevent new policies promoting the combination of work and family from having an immediate effect in Germany, and further policy improvements will have little further impact in France. Taken together, our results suggest that shared attitudes towards childcare and the role of mothers, which are historically shaped by policy environments, and act as an intermediary variable between access to "non parental" child care and its use, are the reason why new policy measures or further policy improvements are not followed by immediate increases in fertility.

Our study has several limitations: first, the sample selection lacks social diversity, especially the Western German sample. This is a major problem when studying the combination of work and family, the opportunity costs of women's time being an important dimension in this issue. Another shortcoming is the rather small sample sizes which did not allow us to reach saturation on the issue of childbearing: some types are thus not well represented, even when pooling both samples together. A third limitation is the focus on young couples, which does not allow us to explore satisfactorily the issue of the third child.

\section{Conclusion}

We found that in France, the model of the economically active mother is well accepted by the population. External child care is not considered to be detrimental to the development of the child or to the relations with its parents. In Western Germany, on the other hand, although women increasingly wish to remain active, care of children under three years of age is thought of as a matter for mothers; to entrust one's child to a third person is considered as a rejection of parental responsibility. We found that these individual attitudes faithfully reflect the approaches to family policy that have been applied for many decades in both countries. We also found that these different attitudes and practices relating to child care and women's work are accompanied by - and thus explain - different fertility intentions and outcomes in both countries. 
These results will be of little surprise to sociologists working in the area of the family and knowing France and Germany: it will be obvious to them that family policies are built on certain visions of the family, and that policies in turn reinforce and crystallize individuals' representations and practices of childrearing, which then shape their fertility behaviours. We hope that our results will encourage demographers to consider that individual attitudes towards the combination of work and family are part of the explanation of fertility intentions and outcomes in industrialized countries, and to acknowledge that these representations may even sometimes matter more to explain fertility outcomes than actual or exact childcare availability. The key to the surprisingly weak impact on fertility of specific family policy changes or variations in childcare supply may lie in the importance of cultural factors (of a positive attitude towards working mothers and external childcare) in this area of decision-making.

\section{Acknowledgements}

We thank Laura Bernardi for her interest in and support for qualitative comparisons. We thank the project "Fertility intentions and outcomes: The role of policies to close the gap" supported by the European Commission, DG "Employment, Social Affairs and Equal Opportunities" (Contract Number: VS/2006/0685) for the financial support of the French data collection, the Institut National d'Etudes Démographique for additional funds for the French data collection, the Institut Emilie du Châtelet for a post doctoral fellowship in 2007-2008 which supported the analysis of the French data, the IRG and the MPIDR for funding the German data collection and analysis, Sylvia Keim and Andreas Klärner for their help in accessing and understanding the German data, Nicole Heikel who was an enthusiastic intern on the project, and Catriona Dutreuilh for English translation and editing. 


\section{References}

Adler, M.A. and Brayfield, A. (2006). Gender regimes and cultures of care: Public support of maternal employment in Germany and the United States. Marriage and Family Review 39(3-4): 229-253. doi:10.1300/J002v39n03_02.

Almqvist, A.-L. (2007). Expectations relating to childcare among French and Swedish families. Community, Work \& Family 10(1): 17-38. doi:10.1080/13668800601110736.

Anttonen, A. and Sipilä, J. (1996). European social care services: Is it possible to identify models? Journal of European Social Policy 6(2): 87-100. doi:10.1177/095892879600600201.

Becker G.S. (1981). A Treatise on the family. Cambridge: Harvard University Press.

Bernardi, L., Keim, S., and Von der Lippe, H. (2007). Social influences on fertility. A comparative mixed methods study in Eastern and Western Germany. Journal of Mixed Methods Research 1(1): 23-47. doi:10.1177/2345678906292238.

Bernardi, L., Klärner, A., and Von der Lippe, H. (2008). Job insecurity and the timing of parenthood: A comparison between Eastern and Western Germany. European Journal of Population 24(3): 287-313. doi:10.1007/s10680-007-9127-5.

Bernhardt, E., Noack, T., and Lyngstad, T.H. (2008). Shared housework in Norway and Sweden: Advancing the gender revolution. Journal of European Social Policy 18(3): 275-288. doi:10.1177/0958928708091060.

Breton, D. and Prioux, F. (2008). The one-child family: France in the European context. Demographic Research 20(27): 657-692. doi:10.4054/DemRes.2009.20.27.

Bundesministerium für Familie, Senioren, Frauen und Jugend (2009). Elterngeld und Elternzeit. Das Bundeselterngeld- und Elternzeitgesetz. Berlin. http://www.bmfsfj.de/RedaktionBMFSFJ/Broschuerenstelle/Pdf-Anlagen/Eltern geld-und-Elternzeit, property $=\mathrm{pdf}$,bereich $=\mathrm{bmfsfj}, \mathrm{sprache}=\mathrm{de}, \mathrm{rwb}=$ true.pdf.

Dearing, H., Hofer, H., Lietz, C., Winter-Ebmer, R., and Wrohlich, K. (2007). Why are mothers working longer hours in Austria than in Germany? A comparative microsimulation analysis. Fiscal Studies 28(4): 463-495.

Dorbritz, J. (2005). Kinderlosigkeit in Deutschland und Europa: Daten, Trends und Einstellungen. Zeitschrift für Bevölkerungswissenschaft 4: 359-407.

Dorbritz, J. (2008). Germany: Family diversity with low actual and desired fertility. Demographic Research 19(17): 557-598. doi:10.4054/DemRes.2008.19.17. 
Dorbritz, J. and Fux, B. (1997). Einstellungen zur Familienpolitik in Europa. Ergebnisse eines vergleichenden Surveys in den Ländern des European Comparative Survey on Population Policy Acceptance (PPA). München: Boldt. (Schriftenreihe des Bundesinstituts für Bevölkerungsforschung).

Dorbritz, J., Lengerer, A., and Ruckdeschel, K. (2005). Einstellungen $z u$ demografischen Trends und zu bevölkerungsrelevanten Politiken. Ergebnisse der PPA Study in Deutschland. Wiesbaden: Bundesinstitut für Bevölkerungsforschung.

Ekert-Jaffé, O., Joshi, H., Lynch, K., Mougin, R., Rendall, M., and Shapiro, D. (2002). Fertility, timing of births and socio-economic status in France and Britain: Social policies and occupational polarization. Population-E 57(3): 475-507. doi: $10.2307 / 3246636$.

Esping-Andersen, G. (1990). The three worlds of welfare capitalism. Cambridge: The Policy Press.

Ette, A. and Ruckdeschel, K. (2007). Grandma makes the difference! The impact of institutional and informal support for parents on their further fertility intentions. Zeitschrift für Bevölkerungswissenschaft 1-2: 51-72.

Fagnani, J. (1992). Travail et fécondité en France et en Allemagne de l'Ouest. Les Françaises font-elles des prouesses? Revue française des affaires sociales 2: 129-148.

Fagnani, J. (2000). Un travail et des enfants. Petits arbitrages et grands dilemmes. Paris: Bayard.

Fagnani, J. (2002). Why do French women have more children than German women? Family policies and attitudes towards child care outside home. Community, Work and Family 5(1): 103-120. doi:10.1080/1366880022010218.

Fagnani, J. and Math, A. (2008). Policy packages for families with children in 11 European countries: Multiple approaches. Comparative Social Research 25: 55-78. doi:10.1016/S0195-6310(07)00002-6.

Fagnani, J., Math, A., and Meilland, C. (2009). Comparaison européenne des aides aux familles. Paris: CNAF.

Gauthier, A.H. (1996). The State and the family. A comparative analysis of family policies in industrialized countries. Oxford: Clarendon Press. 
Gauthier, A.H. (2007). The impact of family policies on fertility in industrialized countries: A review of the literature. Population Research and Policy Review 26(3): 323-346. doi:10.1007/s11113-007-9033-x.

Goldstein, J., Lutz, W., and Testa, M.R. (2003). The emergence of subreplacement family size ideals in Europe. Population Research and Policy Review 22(5-6): 479-496. doi:10.1023/B:POPU.0000020962.80895.4a.

Gornick, J., Meyers, M., and Ross, K. (1997). Supporting the employment of mothers: Policy variation across fourteen welfare states. Journal of European Social Policy 7(1): 45-70. doi:10.1177/095892879700700103.

Hank, K. and Kreyenfeld, M. (2003). A multilevel analysis of child care and women's fertility decisions in Western Germany. Journal of Marriage and Family 65(3): 584-596. doi:10.1111/j.1741-3737.2003.00584.x.

Hantrais, L. (2004). Family policy matters: Responding to family change in Europe. Bristol: The Policy Press.

Henz, U. (2008). Gender roles and values of children: Childless couples in East and West Germany. Demographic Research 19(39): 1451-1500. doi:10.4054/DemRes.2008.19.39.

Hoehn, C., Ette, A., and Ruckdeschel, K. (2006). Kinderwünsche in Deutschland. Konsequenzen für eine nachhaltige Familienpolitik. Bundesinstitut für Bevölkerungsforschung. Robert Bosch Stiftung. http://www.bibdemographie.de/cln_099/nn_750464/SharedDocs/Publikationen/DE/Download/ Broschueren/kinderwunschstudie_2006,templateId=raw,property=publicationFi le.pdf/kinderwunschstudie_2006.pdf.

Hoem, B. (1993). The compatibility of employment and childbearing in contemporary Sweden. Acta Sociologica 36(2): 101-120. doi:10.1177/000169939303600202.

Hoem, B. and Hoem, J.M. (1989). The impact of women's employment on second and third births in modern Sweden. Population Studies 43(1): 47-67. doi:10.1080/0032472031000143846.

Honekamp, I. (2008). Family policy in Germany: Appraisal and assessment. Journal of Family History 33(4): 452-464. doi:10.1177/0363199008323356.

Huinink, J. (2002). Polarisierung der Familienentwicklung in europäischen Ländern im Vergleich. In: Schneider, N.F. and Matthias-Bleck, H. (eds.). Elternschaft heute. Gesellschaftliche Rahmenbedingungen und individuelle Gestaltungsaufgaben. Opladen: Leske+Budrich: 49-73. 
Kangas, O. and Rostgaard, T. (2007). Preferences or institutions? Work-family life opportunities in seven European. Journal of European Social Policy 17(3): 240-256. doi:10.1177/0958928707078367.

Kaufmann, F.-X., Kuijsten, A., Schulze, H.-J., and Strohmeier, K.P. (2002). Family Life and Family Policies in Europe. Oxford University Press.

Koeppen, K. (2006). Second births in Western Germany and France. Demographic Research 14(14): 295-330. doi:10.4054/DemRes.2006.14.14.

Konietzka, D. and Kreyenfeld, M. (2002). Women's employment and non-marital childbearing: A comparison between East and West Germany in the 1990s. Population-E 57(2): 331-357. doi:10.2307/3246612.

Kravdal, Ø. (1992). The emergence of a positive relationship between education and third birth rates in Norway with supportive evidence from the United States. Population Studies 46(3): 459-475. doi:10.1080/0032472031000146456.

Kreyenfeld, M. (2002). Time-squeeze, partner effect or self-selection? An investigation into the positive effect of women's education on second birth risks in West Germany. Demographic Research 7(2): 15-48. doi:10.4054/DemRes.2002.7.2.

Kreyenfeld, M. and Hank, K. (2000). Does the availability of child care influence the employment of mothers? Finding from Western Germany. Population Research and Policy Review 19(4): 317-337. doi:10.1023/A:1026556309080.

Le Goff, J.-M. (2002). Cohabiting unions in France and West Germany: Transitions to first birth and first marriage. Demographic Research 7(18): 593-624. doi:10.4054/DemRes.2002.7.18.

Lengerer, A. (2004). Family policy regimes in Europe and their relevance for the change of the family. An overview of the state of the art. Zeitschrift für Bevölkerungswissenschaft 1: 99-121.

Lestrade, B. (2004). Le travail à temps partiel en France et en Allemagne: deux modèles contrastés. Innovations, Cahiers de l'économie 2(20): 59-82. doi:10.3917/inno.020.0059.

Lewis, J. and Ostner, I. (1995). Gender and the evolution of European social policies. In: Leibfried, S. and Pierson, P. (eds.). European Social Policy: Between Fragmentation and Integration. Washington D.C.: The Brookings Institution: 159-193. 
Luci, A. (2010). Finanzielle Unterstützung von Familien in Deutschland und Frankreich. Hat Frankreich für erwerbstätige Mütter die Nase vorn? Zeitschrift für Sozialreform 56(1): 3-28.

McDonald, P. (2005). Low fertility and the state: The efficacy of policy. Population and Development Review 32(3): 485-510. doi:10.1111/j.17284457.2006.00134.x.

Milewski, N. (2007). First child of immigrant workers and their descendants in West Germany: Interrelation of events, disruption, or adaptation? Demographic Research 17(29): 859-896. doi:10.4054/DemRes.2007.17.29.

Motiejunaite, A. and Kravchenko, Z. (2008). Family policy, employment and genderrole attitudes: A comparative analysis of Russia and Sweden. Journal of European Social Policy 18(1): 38-49. doi:10.1177/0958928707084453.

Neyer, G. (2003). Family policies and low fertility in Western Europe. Journal of Population and Social Security (Population) 1(Supplement): 46-93.

Oláh, L.S. (1996). The impact of public policies on the second-birth rates in Sweden: A gender perspective. Stockholm (Stockholm Research Reports in Demography 96)

Onnen-Isemann, C. (2003). Familienpolitik und Fertilitätsunterschiede in Europa, Frankreich und Deutschland. Aus Politik und Zeitgeschichte B44: 31-37.

Périvier, H. (2004). Emploi des mères et garde des jeunes enfants en Europe. Revue de l'OFCE 3(90): 224-258. doi:10.3917/reof.090.0225.

Pinl, C. (2003). Uralt aber immer noch rüstig: Der deutsche Ernährer. Aus Politik und Zeitgeschichte B44: 6-8.

Purr, A., Oláh, L.S., Tazi-Preve, M.I., and Dorbritz, J. (2008). Men's childbearing desires and views of the male role in Europe at the dawn of the $21^{\text {st }}$ century. Demographic Research 19(56): 1883-1912. doi:10.4054/DemRes.2008.19.56.

Rossier, C. and Bernardi, L. (2009). Social interaction effects on fertility: Intentions and behaviors. European Journal of Population 25(4): 467-485. doi:10.1007/s10680-009-9203-0.

Salles, A. (2004). L'allocation parentale d'éducation en France et en Allemagne: un instrument au service d'une meilleure conciliation entre travail et famille? Innovations, Cahiers d'économie de l'innovation 2(20): 93-115. doi:10.3917/inno.020.0093. 
Salles, A. (2006). La politique familiale allemande: les limites de l'action de l'Etat. Critique Internationale 2(31): 95-117. doi:10.3917/crii.031.0095.

Saxonberg, S. and Sirovatka, T. (2006). Seeking the balance between work and family after communism. Marriage and Family Review 39(3-4): 287-313. doi:10.1300/J002v39n03_04.

Schroder, J. and Bruderl, J. (2008). Female labor force participation and fertility: An analysis of the transition to parenthood in West Germany. Zeitschrift für Soziologie 37(2): 117-136.

Sjöberg, O. (2004). The role of family policy institutions in explaining gender-role attitudes: A comparative multi-level analysis of thirteen industrialized countries. Journal of European Social Policy 14(2): 107-123. doi:10.1177/0958928704042003.

Spiess, C.K. and Wrohlich, K. (2008). The parental leave benefit reform in Germany: Costs and labour market outcomes of moving towards the Nordic model. Population Research and Policy Review 27(5): 575-591. doi:10.1007/s11113008-9086-5.

Statistisches Bundesamt (2009). Mikrozensus 2008 - Neue Daten zur Kinderlosigkeit in Deutschland. Wiesbaden: Statistisches Bundesamt. http://www.destatis.de/ jetspeed/portal/cms/Sites/destatis/Internet/DE/Presse/pk/2009/Kinderlosigkeit/be gleitheft_Kinderlosigkeit,property=file.pdf.

Strohmeier, K.-P. (2002). Familienpolitik und Familienleben in Europa. In: Dorbritz, J. and Johannes, O. (eds.). Familienpolitik und Familienstrukturen. Wiesbaden: BiB-Materialien zur Bevölkerungswissenschaft: 109-120.

Testa, M.R. (2006) Childbearing preferences and family issues in Europe. Evidence from the Eurobarometer 2006 survey. Vienna Yearbook of Population Research 2007: 357-379. doi:10.1553/populationyearbook2007s357.

Testa, M.R. and Grilli, L. (2006). The influence of childbearing regional contexts on ideal family size in Europe. Population 61(1-2): 107-137. doi:10.3917/pope.601.0099.

Thévenon, O. (2008). Does fertility respond to work and family-life reconciliation policies in France? Paper presented at the CESifo Conference on fertility and public policy, Munich, February 1-2, 2008.

Toulemon, L. (2006). Fertility Among Immigrant Women and Men in France: New Data, New Approach. Paper presented at the Population Association of 
American 2006 Annual Meeting, Los Angeles, California, March 30-April 1, 2006.

Toulemon, L., Pailhé, A., and Rossier, C. (2008). France: High and stable fertility. Demographic Research 19(16): 503-556. doi:10.4054/DemRes.2008.19.16.

Veil, M. (2003). Wohlfahrtsstaatliche Konzepte, Kinderbetreuungskulturen und Geschlechterarrangements in Europa. [electronic resource]. Gender...Politik...online. http://web.fu-berlin.de/gpo/. 


\section{Annex 1: Age, marital status, number of children and occupational status of the Western German respondents}

\begin{tabular}{|c|c|c|c|c|}
\hline Name & Age & Marital status & Number of children & Occupational status \\
\hline Amelie & 32 & single & childless & educator, jobless \\
\hline Anja & 29 & $\mathrm{LAT}^{10}$ & childless & senior clerk human resources \\
\hline Arno & 30 & LAT & childless & journalist \\
\hline Bärbel & 31 & married & two children & training course (naturopath) \\
\hline Britta & 29 & married & one child & at home, physiotherapist (in training course) \\
\hline Christin & 30 & in couple & childless & psychologist \\
\hline Claudia & 33 & married & childless & student \\
\hline Franziska & 29 & married & one child & teacher (husband in parental leave) \\
\hline Inge & 39 & married & one child & at home, biologist \\
\hline Jan & 30 & single & childless & call center agent and student \\
\hline Jürgen & 31 & single & childless & security adviser \\
\hline Julia & 34 & single & childless & dental hygienist \\
\hline Kathrin & 29 & in couple & childless & studied business economics, clerk \\
\hline Lars & 27 & single & childless & dairy expert \\
\hline Maike & 31 & in couple & childless & student \\
\hline Markus & 28 & married & one child & bank clerk (wife in part time) \\
\hline Martin & 29 & LAT (engaged) & childless & technical sales representatives \\
\hline Martina & 30 & LAT & childless & restoring furniture \\
\hline Matthias & 29 & married & childless & portfolio manager \\
\hline Melanie & 33 & married & one child & postwoman, part time \\
\hline Nadia & 31 & LAT & childless & white collar worker \\
\hline Nina & 30 & in couple & childless & student \\
\hline Ozan & 28 & married & one child & technical sales representatives (wife at home) \\
\hline Paul & 31 & married & childless & student \\
\hline Paula & 31 & in couple & childless & administrative clerk \\
\hline Petra & 29 & married & one child & at home, insurance agent \\
\hline Ralf & 28 & single & childless & student \\
\hline Stefan & 31 & LAT & childless & student \\
\hline Susanne & 30 & LAT & childless & insurance agent \\
\hline Thomas & 31 & married & childless & white collar worker \\
\hline Tilman & 37 & married & one child & commercial agent (wife at home) \\
\hline Tobias & 31 & married & two children & employee in a public service (wife at home) \\
\hline Ulla & 29 & in couple & pregnant & manager \\
\hline Ulrich & 29 & single & childless & student \\
\hline Wiebke & 29 & LAT & childless & veterinarian assistant \\
\hline
\end{tabular}

${ }^{10}$ LAT: Living Apart Together is a term for couples who, whilst committed to each other, are living in separate homes. 
Annex 2: Age, marital status, number of children and occupational status of the French respondents

\begin{tabular}{|c|c|c|c|c|}
\hline Name & Age & Marital status & Number of children & Occupational status \\
\hline Alice & 27 & LAT & childless & translator \\
\hline Amandine & 28 & married & one child & $\begin{array}{l}\text { white collar worker in an pharmaceutical } \\
\text { laboratory }\end{array}$ \\
\hline $\begin{array}{l}\text { Anne- } \\
\text { Sophie }\end{array}$ & 28 & cohabiting & two children & on parental leave, no employment \\
\hline Ariane & 30 & single & childless & customer manager \\
\hline Benoît & 27 & LAT & childless & actor \\
\hline Camille & 29 & married & two children & teacher \\
\hline Damien & 30 & married & two children & fireman \\
\hline David & 30 & single & childless & teacher \\
\hline Dominique & 29 & $\begin{array}{l}\text { in (homosexual) } \\
\text { couple }\end{array}$ & one child & marketing assistant \\
\hline Elise & 28 & LAT & childless & white collar worker in clinical research \\
\hline Eric & 32 & married & two children & fireman \\
\hline Etienne & 31 & married & two children & commercial \\
\hline Fabien & 28 & single & childless & nurse \\
\hline Franck & 29 & single & childless & fiscal agent \\
\hline Hélène & 30 & single & childless & psychiatric nurse \\
\hline Jérémy & 28 & cohabiting & childless & chemist, looking for a job \\
\hline Justine & 30 & LAT & childless & commercial assistant \\
\hline Karine & 29 & cohabiting & childless & customer manager \\
\hline Marie & 29 & cohabiting & one child & policewoman \\
\hline Patrick & 27 & single & childless & student \\
\hline Sammy & 33 & cohabiting & two children & computer manager in an association \\
\hline Sandrine & 30 & cohabiting & one child & accountant \\
\hline Sofia & 29 & cohabiting & one child & temporary part-time work in an association \\
\hline Sylvain & 31 & married & three children & joiner \\
\hline Sylvie & 28 & LAT & childless & management assistant \\
\hline Thierry & 32 & married & one child & engineer in an architect office \\
\hline Valentine & 28 & separated & one child & manager in the building trade \\
\hline
\end{tabular}


Salles, Rossier, \& Brachet: Understanding long term effects of family policies on fertility 